ARTICLE

https://doi.org/10.1057/s41599-019-0333-7

\title{
The logic of the slave patrol: the fantasy of black predatory violence and the use of force by the police
}

\author{
Laurence Ralph ${ }^{1 \star}$
}

\begin{abstract}
The background context for this study is the relationship between the right to bear arms and the role of policing in the United States. The fact that the second amendment guarantees the right to bear arms and the correlative right to form "a well-regulated militia" have long been central to the scholarly understanding of the role of guns in American society. Yet few social scientific studies have taken the friction between militias and the burgeoning police departments of the 1800s as a point of departure for present-day debates about the police's use of force. For the early part of US history, many citizens feared that the police would attempt to supplant militias. In some southern cities, like New Orleans, residents argued that if the city government was going to let the police patrol the city, they should do so without guns. It was the threat of slave uprisings that ended the conflict between militias and the police. A major implication of this study is that rooting the contemporary understanding of police violence in early debates about the police's use of force can help social scientists better understand how policing is understood and experienced today. Indeed, the African Americans interviewed for this study view the gun in the hands of a police officer as a technology that is rooted in the slave patrol. This is because it is the descendants of enslaved people who are disproportionately subject to police shootings. The article demonstrates this point by exploring a 2014 police shooting. The shooting of Laquan McDonald garnered national attention when, on October 20, 2014, Chicago police Officer, Jason Van Dyke, shot the 17-year-old Black teenager 16 times. The methods employed in this study include: archival data on the early use of force debate, discourse analysis of court testimony from Van Dyke's 2018 first degree murder trial, and semi-structured interviews with Chicago residents who discuss this case. Ultimately, this study finds that in the McDonald shooting, the gun helps to reproduce the fantasy of Black predatory violence that is rooted in slavery.
\end{abstract}

\footnotetext{
${ }^{1}$ Department of Anthropology, Princeton University, Princeton, NJ 08544, USA. *email: Iralph@princeton.edu
} 


\section{Introduction}

ecently new data has surfaced to confirm what Black people have been alleging for centuries: African Americans are policed and punished far more severely than their white counterparts. In November of 2017, the US Sentencing Commission issued a report, based on "multivariate regression analyses," which stated that "black defendants...receive longer

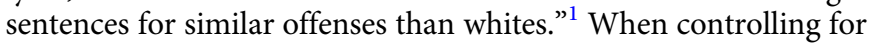
social factors like whether or not someone had committed a crime, or a person's age, or someone's level of education, or citizenship status, the Commission found that, from 2012 to 2016, "Black male offenders received sentences on average 19.1\% longer than similarly situated White male offenders." ${ }^{2}$ As if to prove that a prediction made seven years prior had finally come to pass, the Commission's report referenced their own prognostication from 2010, which stated that "Black male offenders received longer sentences than White male offenders and that the gap between the sentence lengths... was increasing."3 Sentencing disparities, of course, are only one example of the perception that African Americans are more criminal than other racial groups living in the United States.

Another powerful indicator of inequity in the US legal system is the outsized risk that the police pose to Blacks. In 2013, ProPublica published one of the most comprehensive analyses of racial disparities in deadly police encounters to date. Their examination included "detailed accounts of more than 12,000 police homicides stretching from 1980 to 2012. They collected this information from the Federal Bureau of Investigation's Supplementary Homicide Report. ${ }^{4}$ ProPublica found that young Black males were at "a far greater risk" of being shot and killed by police than their white peers. In fact, they were 21 times more likely to be fatally shot over this two decade period. ${ }^{5}$ The data showed, more specifically, that "Blacks, age 15 to 19, were killed at a rate of 31.17 per million, while just 1.47 per million white males in that age range died at the hands of the police." 6 These figures do not even account for the fact that white males during this period made up $31 \%$ of the American population, while the total number of African Americans (both men and women) comprised $13 \%$.

The ProPublica report also highlighted data which paint a compelling picture of how fatal police shootings typically take place: Most of the time (on $91 \%$ of the occasions, to be exact) white officers fired the shot that fatally killed a civilian. Sixty-eight percent of the time, those slain civilians were Black. The data also showed that, after these fatal shootings, it was common for the police to report that they feared for their lives. Importantly, the report points out that this rationale became substantially more common after a 1985 Supreme Court decision, Tennessee $v$. Garner, in which the justices ruled that police could use deadly force if the suspect posed a threat to the police officer or others. In the four years preceding Tennessee v. Garner, "officer under attack" was cited in just $33 \%$ of police killings. But twenty years later, it was cited $62 \%$ of the time, becoming an almost infallible means for police officers to defend themselves.

The United States federal government has not made data on police shootings available to the public in any systematic way since the ProPublica report in 2013, despite a number of high profile fatal police shootings that have drawn the attention of national and international news media outlets. While the Death in Custody Reporting Act of 2014 mandated that law enforcement agencies across the country provide basic information about people killed by the police or in police custody, the extent to which police departments across the nation have complied with this Act is unclear. Fortunately, citizen-led organizations have filled this void.
The organization, Mapping Police Violence, currently maintains the most comprehensive database on police killings in the United States. According to their website, Mapping Police Violence sources their information from "the largest most comprehensive databases on police killings in the country," including: FatalEcounters.org, the US Police Shooting Database, and KilledbyPolice.net. This organization also conducts original research to improve the quality of the data they collect by scouring social media, scanning obituaries of those killed by police, searching through criminal records databases that reference fatal police encounters, and investigating police reports connected to police shootings. The result is that the data culled by this organization comprises the most complete accounting of police killings in the US to date.

Mapping Police Violence has collected information on 6782 fatal police shootings from January 2013 to December $2018 .{ }^{7}$ They find that, of the 1147 people killed by the police in 2017, $25 \%$ were Black (again, despite being only $13 \%$ of the population). Black people, in fact, were three times more likely to be killed by the police than their white counterparts. Crucially, these findings contradict some of the prevailing associations with race and criminality-namely the assumption that police officers kill Blacks at a higher rate because Black people commit more crimes, and therefore pose a greater threat to those officers. The data show that "fewer than 1 and 3 Black people killed by the police in 2014 were suspected of a violent crime" and $69 \%$ of those killed were unarmed. What is more, "levels of crime in US cities do not make it any more or less likely for police to kill people." One of the most prominent findings about policing in the contemporary moment has to do with the level of impunity that officers enjoy. When it comes to police killings, "99 percent of the cases in 2015" did not result in any officer involved being convicted of a crime. ${ }^{8}$

The quantitative data from Mapping Police Violence, together with the US Sentencing Commission report and the earlier ProPublica report, prove useful in demonstrating that Black people in the United States are perceived to be more dangerous than other racialized populations-and that they are killed because of this perception. But not just this, the data illuminates the typical scenarios for these fatal encounters: White police officers tend to kill Black males, and then claim that they feared for their lives, even though the frequency of police killings does not correlate with the frequency of crime in US cities. In fact, most of the people who are shot by the police have not committed a crime, and are not armed. But while this data demonstrates racial disparities in sentencing, as well as fatal police shootings, it does not say anything of the historical and social context that informs the police's use of force. This article serves as a corrective.

Since Black people who are fatally shot by the police are killed by officers with guns, the historical context for the broader study of which this article is a part, is the relationship between the right to bear arms and the role of policing in the United States. The Second Amendment guarantees the right to bear arms and the correlative right to form "a well-regulated militia-twinned entitlements that have long been central to the scholarly understanding of the role of guns in American society. Yet few social scientific studies have taken the friction between militias and the burgeoning police departments of the 1800s as a point of departure for present-day debates about the police's use of force. Taking these debates as a point of departure, this paper argues that it is only by understanding how the gun helps reproduce the fantasy of Black predatory violence that one can fully comprehend the nature of the aforementioned statistics, which is to say, how a vision of Blackness rooted in fear, exclusion and criminality serves to underpin the US legal system today. 
The gun and the police use of force. One of the earliest renditions of the police use of force debate took place in New Orleans, Louisiana in 1830, the first year in the city's history that a police officer with a gun took the life of a civilian. Police officers in New Orleans began carrying guns twenty-five years earlier, following the Haitian Revolution, when the municipal government enlisted a domestic armory to enforce a new decree that Blacks-be they enslaved or free-were no longer allowed to immigrate to the city (Wagner, 2010). The local government had been living in fear of a major attack from Black people for seventy-five years, ever since the Natchez Massacre of 1729 , when fugitive slaves united with Native Americans like the Natchez and Choctow to demand their autonomy from the French colonial government (Genovese, 1992). It was the alliance between African descendants and Native Americans, in fact, that eventually led the New Orleans government to create their first slave patrol thirty years later, in 1764 (Ingersoll, 1995). Slave patrols were critical to slaveowners, who had previously been forced to expend their own resources to capture these so-called fugitives (Williams, 1972). The existence of slave patrols also helped city government officials argue that they needed to provide protection to the broader public through armed patrol (Wish, 1939; Williams, 1972; Wagner, 2010).

When the idea of an armed police force was introduced to New Orleans residents in the 1800s, many of the white residents at the time disapproved or were outright angered at the prospect, the implication being that the government wanted to treat them like slaves (Wagner, 2010). Most New Orleans residents did not own slaves, but the white residents understood why it was useful to have an armed patrol to catch fugitive Blacks. But if that patrol was allowed to arrest and shoot them too? Well, that was an idignity, which was difficult for them to understand. A critical mass of whites felt that the government had unduly encroached on their civil liberties by appointing a "well-filled armory" in "plain blue uniforms" to monitor their movements." And after the fatal police homicide of 1830 , an event that seemed to corroborate their fears about a weaponized police force, they created a reform campaign.

For the reformers, police violence was not a signal of progress but a holdover from an archaic past when patrols could enact any form of violence on enslaved people that they deemed fit. Because they viewed the police as an extension of the slave patrol, they argued that "police represented the abrogation of the rule of law." ${ }^{10}$ This argument would win the day as the New Orleans police lost the right to carry guns after the 1830 shooting. In 1836, the city council passed an ordinance that removed all weapons from the police except for their nightsticks. As a result, the police in New Orleans started to look more like the lightly armed patrols in New York, Boston, and Philadelphia who, at the time, did not use guns (Hastings, 1900). The New Orleans police would not win back their legal right to firearms for decades to come.

This debate is relevant to the fatal police shootings today, as many of the African Americans who participated in this study view police violence like the early reformers did: They see the issue as a matter of gun control.

Research method and process. The wider study upon which this research is based seeks to investigate how African Americans understand themselves as a people to be feared. The ethnographic fieldwork methods employed in this study were typical of those used in anthropology and sociology. Over the course of several years (from 2014 to 2018), the principal investigator (PI) attended rallies and marches on police violence and community forums on the Chicago Police Department's use of force, conducting participant observation at such events. He reviewed case files of the victims of high profile police brutality cases, some of whom he had listened to at public rallies. The PI also scanned the city newspapers for articles mentioning police violence. In the period that the PI engaged in this work, he found $~ 500$ articles that were especially relevant to this study. After the PI coded this material and had a sense of which documents were important to understanding contemporary debates about the police's use of force, he used these primary sources to structure interviews and group discussions about police violence, more broadly.

The purpose of qualitative interviews were to explore the ways that Chicago residents were making sense of police violence in their city. To assess the impact of the police's use of force on everyday Chicagoans, The PI conducted both focus groups and interviews with three groups of interest: youth of color in Chicago, victims of police violence, and other Chicago residents. The combination of focus groups and in-depth interviews allowed the PI to speak to more than one hundred residents in total. Focus groups had the added benefit of increased topic coverage as respondents in the group cued others about relevant concepts and reactions that made for a richer qualitative data set. Meanwhile, in-depth interviews allowed for the exploration of a narrower set of concepts and reactions in more depth with a select number of respondents.

Recruitment for these interviews chiefly relied on recruiting in public spaces in Chicago. For each of the groups of interest, recruitment ended when the PI reached the point of saturation. ${ }^{11}$ Approximately thirty-five Chicago youth of color (between the ages of 14 and 18-years-old) were recruited; twenty-six victims of Chicago police violence were also recruited; and thirty-six Chicago residents from various backgrounds and professions were recruited. The goal of recruitment was to get a cross section of Chicago residents from different areas of the city with regard to age, race, and gender. Half the residents who participated were men and half were women. Their ages ranged from 18 to 51years-old. As mentioned, they came from diverse racial and ethnic backgrounds. They also resided in a variety of geographical areas in the city.

For this project, in other words, the PI set out to speak with any Chicagoan who was willing and able to talk, no matter his or her race or socioeconomic status, about the role they believed the police should play in their society. Out of the 100 Chicagoans who were interviewed for this study, 53 identified as Black. The remarkable thing about the Black respondents was how much their stories of police violence resonated with each other, and yet differed from the respondents of other races. Even if they themselves had not personally been victimized by the police (a rare occurrence among the group), the Black respondents expressed solidarity with victims of police violence through the stories they had carried with them their entire lives. For the purposes of this article, the PI has chosen to focused on one interview that is representative of the way that Black respondents feel about the use of force in their city.

"Kenya's" story resonated with people in other groups. She grew up in Chicago, which might help to explain why her experiences were similar to the cohort of young respondents; she had witnessed acts of police violence, and so her feelings about the police resonated with many victims; and yet, she had substantial educational and professional experiences which allowed her to understand the perspectives of non-Black respondents of this study. In what follows, a particular case of police violence, the death of Laquan McDonald, will be discussed through her eyes.

Kenya's journey. Kenya Davis is a twenty-five-year-old middle school teacher who considers herself, among other things, a police and prison abolitionist. ${ }^{12}$ She was born and raised in Chicago, a 
city known for its activist roots, but she did not start organizing until she was miles from home, at college. As she remembers it now, two defining features of her college were that it was predominantly white and profoundly privileged. "A couple of years ago," she said, "The New York Times wrote an article entitled, 'Where does the top one percent send their kids?"'13 Her college was number two on the list.

Initially Kenya felt as though she were living in a bubble, and she was comfortable being enclosed and protected within it. But every now and then, an interaction with one of her classmates would penetrate the protective sphere she had constructed for herself, reminding her that even though she felt safe from the world outside, her classmates viewed the bubble she cherished as a cage in a zoo. "They had some basic assumptions and stereotypes about Black folks," Kenya told me. "Like somebody said, 'Oh, you're from the South Side of Chicago. You must be from the projects'." When her classmates would make comments like this, Kenya found herself in the unenviable position of having to correct the erroneous claim ("No, I am not from the projects"), as well as having to correct the stereotype upon which the claim was based ("But even if I was, there wouldn't be anything wrong with that"). In this case, she could not understand whether her classmate intended to pay her a compliment, or remind her that she was lucky for being accepted there, or to suggest that she was undeserving. All she knew was that with each passing semester, she was continuously reminded that she was different than most of the white students enrolled with her. At first she experienced her stigma in a solitary way. But when the issue of state sanctioned violence and the police's use of force began to receive renewed national attention in the early 2000s, Kenya was compelled to action.

"There was a man named Troy Davis," she said. "He was on death row in the South, and he was killed at the hands of the state. But there was a lot of evidence that he didn't really do this crime." Kenya spoke about the witnesses who recanted their original testimony, and the Black residents of Davis's hometown who had been trying to exonerate him for decades. When the state of Georgia executed him on September 21, 2011, as Kenya now recalls, "It was a very sad day on campus" for activists like her. After Davis's execution, Kenya started to connect the racism she had experienced throughout the course of her life to the statesanctioned violence that was happening outside of campus. When she was talking to her classmates about how a seemingly innocent man was about to be sentenced to death, "no one on campus really cared." And after Davis's death, when she and the other Black students held a rally in Colorado Springs, the major city adjacent to her college, she understood that the racism she had encountered was not merely the result of her classmates' naiveté. It was far more insidious.

"When we were walking down the street, people were spitting at us." Kenya found the response shocking because all she was doing was exercising her First Amendment right to assemble peacefully. This was a big deal for her. Back then Kenya did not have the language to pinpoint exactly what was wrong. But now, if she could speak to the white residents of that city, the people who yelled and cursed and spat at her as she marched downtown in the hopes of saving a man's life, she would say a few words to make them contemplate their actions: "Somebody has been murdered. And y'all are so anti-Black, y'all are so racist, that you are angry that I'm walking down the street?"

Kenya now counts Troy Davis's execution as a milestone on a journey to becoming more politically aware about the use of force in the legal system. She now realizes that the use of force is not merely relevant for people like Davis who were locked up because they may have been wrongfully accused. It affects every day Black people like her as well.
It is important to point out that Kenya's critique here was not merely about the lethal injection that took Davis's life. It was expressly about the gun. "Maybe this is me speaking as a young Black person," she said, "but the police make me nervous. And the police make all of my students nervous. They make everyone I know nervous. Regardless of whether or not you have done anything wrong, when the police drive past you, when the police are in the building, when they're in the space with you, they make you nervous."

Kenya elaborated, explaining that the police are so preoccupied with solving crimes that they end up harassing people based on the same kind of assumptions that would lead someone to believe, for example, that all Black people from the South Side of Chicago come from the projects. Then she said something that pointed to the implications of this implicit bias. Kenya said that what concerned her most of all was that the police's assumptions about Black people could be a matter of life and death: "So when a police officer is near me, it makes me very nervous. You have to understand: this person is armed. To me, the fact that they have a gun and the power to take a life puts fear in me. I'm very terrified of the police." When Kenya said these words, they instantly struck a chord with the other Black respondents in this study. While feelings about the police varied for the non-Black interviewees, all of the African Americans reported not feeling safe around the police. Those Black interviewees, including Kenya, likely did not know it, but in voicing their anxiety over the police's use of force, they were revisiting a very old debate about whether or not the police should be able to carry guns.

The legacy of force. It is somewhat ironic that a white police reformer from the 1800 s could feel similar to a Black woman born centuries later in the South Side of Chicago-given that many of those reformers believed that Blacks belonged to an inferior race. The key issue that early reformers and contemporary abolitionists agree upon is that giving police officers the discretion to determine who poses a societal threat will inevitably lead to police killings. Back then, the reform campaign concentrated much of its efforts on the scene of arrest, especially on the split second when an officer decided whether to use violence. This decision required discretion and could not be regulated through the law in any transparent way. That is why the reformers interpreted the police officer's ability to take a lethal course of action as a threat to the rule of law itself.

Meanwhile, the advocates of a weaponized police force adopted the now commonly held philosophy that the state's presumptive "monopoly on violence" was a turning point in world history. They argued that political society begins when individuals transfer their personal ability to inflict violence on another citizen to a sovereign with an exclusive right to initiate deadly force. The absolute right to violence, they asserted, is crucial to the defense of the city (ibid). This was the argument most often made by New Orleans mayor, Denis Prieur, a strong supporter of a weaponized police force. ${ }^{15}$ When the reformers tried to strip the police of their guns, Prieur responded by initiating a wellpublicized operation against Bras-Coupé a maroon leader who was meant to epitomize the social threat emanating from the swamps (Wagner, 2010). The Legend of Bras-Coupé, can be recounted as follows:

Once a slave named Squire was hired-out by his owner. A talented performer, he was allowed to travel alone. The problem was that, when Squire traveled, he often failed to return. After numerous escape attempts, the police captured him and amputated his right arm as punishment. Confined to a hospital where his arm was amputated, he got dysentery. As he fell into a state of weakness and unrest, the 
slave patrol suspended its surveillance. Taking advantage of the situation, Bras-Coupé leaped through an open window and fled to the swamp, where he organized a band of fugitives that subsequently terrorized the city-robbing plantations, stores and merchants. Who will defend you from Bras-Coupé, Prieur suggested, if not the police? And how will the police defend you if they are stripped of their guns? ${ }^{16}$

In the police reports that Mayor Prieur read to the public, BrasCoupé is described as "a fiend in human shape," imperceptible except as a threat. Meanwhile, leading local newspapers asserted that "fire shoots from his eyes," while claiming that the police's guns are rendered useless when bullets ricochet from his "ironlike" torso (Wagner, 2010, p. 76). Despite some sensational reportage regarding the Black threat, as previously mentioned, reformers got their wish and the city council passed an ordinance that removed all weapons from the police except for their nightsticks.

But if Prieur and his allies lost the local battle in the short term, they won the war in the long run: the rationale that they dramatized through Bras-Coupé eventually became so pervasive that it no longer had to be explicitly tied to the reform debate (Wagner, 2010). By the beginning of the 1900s, there was no longer a need to argue for the police's need for guns, because that need was no longer in doubt. The public had come to believe that there would always be social threats like Bras-Coupé (ibid). Based upon this kind of moral panic, police power eventually came to seem socially necessary, not only in New Orleans but in every other city and town in the United States.

As if to point to the enduring legacy of this kind of panic, Kenya brought up the recent scandal involving a Black teenager who had been shot sixteen times: "It all reminds me of Laquan McDonald," she said. In the McDonald case, Kenya went on to say, false reports covered over the full extent of police force. On the news that night, for example, reporters said McDonald was shot one time, "when in actuality he was shot many, many more times," she said. The problem with this kind of misrepresentation, for Kenya, is that it allows the public to believe that people are getting punished in line with what they deserve. Because the violence inflicted on McDonald was so out of line with the threat he posed, Kenya felt, the media was motivated to misrepresent the case and the police were determine to hide evidence of their own aggression. Just as newspapers in the 1830 s worked to construe Bras-Coupé as a threat, Kenya believes that the media continues to denigrate Black people to justify police violence by way of the gun (c.f. Dixon, 2008).

In this case, Kenya was adamant about making me aware that it was not just the media that was to blame. Other police officers perpetuated the lie. Kenya spoke about another police officer who was driving by the scene of the crime on the day Van Dyke killed McDonald. "This officer claimed that she looked down to put her car in park, and by the time she looked back up, the shooting was done." Now that video footage of the shooting has been released, Kenya finds this woman's story hard to believe. "We know that there were sixteen shots," Kenya started, "and they didn't happen so quickly," she said, "if anybody is shooting you're going to look up, not down, to ensure your safety-especially if you're a cop."

Kenya's theory is that the police officer did not want to go on record as having witnessed McDonald's shooting, "so she just came up with a narrative that would keep her from being accountable." The police's 'code of silence' exists, according to Kenya, to protect police power, which includes their ability to kill and commit violence when they felt the need. Were the frequency of police violence to be exposed, she insists, it would raise questions about the ways that the police are predisposed to abuse their authority. For Kenya, police abuse covers a vast spectrum, ranging from speaking to residents too harshly to fatal shootings -and she thought the two ends of this spectrum were tied together as if in a knot. "In my opinion," Kenya said, "the police are inherently abusive." She elaborated: "If a cop comes up to me and is verbally assaulting me, that is abuse. Think about it. That person has a gun and they have the power-they have the authority of the state to use their weapon whenever they feel like they're in danger."

The notion that the police's use of force can be tied to their own perception of fear, which can conflict with whether or not they are actually in danger, resonates with early reformers' concerns with discretion. The reformers felt that it was shortsighted and ethically wrong to create a legal norm around a subjective feeling. Perhaps they worried that citizens would be shot arbitrarily. That has not been the case. What has happened, in countless cases involving the police's use of force, including Laquan McDonald's case, as we will see, is that it has become reasonable for a police officer to fear a Black person, in particular.

Kenya said that, in theory, she understood why police officers might need to use lethal force if their life was in danger. Then she posed this question: "What happens when the police use force because they feel like they're in danger?" Perhaps Kenya emphasized this word, "feel," to distinguish the reality of danger from the idea of it. But if there was any doubt that Kenya did not know the answer to the question, she soon clarified her stance: "It's so subjective," Kenya said, still talking about an officer's legal right to feel afraid. "Officers are always feeling like they're in danger, even when they're not," Kenya said, before describing this event: "There was a man who got shot by the police in Minnesota," she started, "and his girlfriend recorded a video of the shooting. In the video, the police officer is literally shaking before he shoots the man. And the man in the car wasn't even doing anything that was endangering the cop. The police officer was still afraid."

The man in the video that Kenya described was Philando Castile. His girlfriend, Diamond Reynolds, and her 4-year-old daughter, were in the car with him when a police officer shot him seven times. The police shooting gained widespread attention, in part, because Reynolds live-streamed the event on Facebook. At one point in the video, Reynolds' phone falls onto the ground, but continues recording. The viewer can no longer see her, but one can hear an officer ordering Reynolds to get on her knees. The sound of Diamond Reynolds being handcuffed is soon followed by a discernable urgency in her daughter's voice: "Mom, please stop cussing and screaming...I don't want you to get shooted."

The gun and the fantasy. Six months after this interview with Kenya, Jason Van Dyke's first degree murder trial began. Van Dyke would take the stand on October 5, 2018, a year and two weeks before he killed Laquan McDonald. ${ }^{17}$ From his court testimony, and from other witnesses to the shooting, the jurors deciding this case would learn that on October 20, 2014, on the southwest corner of 59th and Pulaski, Van Dyke heard a distress call. The call came from a police officer named McElligott who reported that one of the tires on his squad car had been punctured. Van Dyke and his partner, who he had become accustom to calling by his last name, Walsh, had been assigned to the "rapid response car" that night. This meant that it was their duty to report to any calls where officers might need help. Taking heed of their obligation, Van Dyke and Walsh immediately headed towards McElligott's location at the intersection of 40th and Pulaski. While they were driving the nineteen blocks it would take to reach McElligott and his partner, Van Dyke spoke to Walsh about the suspected criminal who had been so bold as to puncture 
the tires of a police car. "Why didn't they shoot him if he's attacking them?" Van Dyke wanted to know. A short time before they reached the person suspected of puncturing the tire, Van Dyke followed this question with an ominous declaration, which could be mistaken for a prophecy perhaps, were it not for the sense of desire Van Dyke displayed for making this wish come true: "Oh my God," he said about the suspect, "we're going to have to shoot the guy."

When they got to 40th and Pulaski, Van Dyke and Walsh saw McElligott pointing with one hand to a "male" wearing a black hoodie and blue jeans. He was apparently evading pursuit, and Van Dyke noticed the person running away from McElligott was carrying a knife. This person was 17-year-old Laquan McDonald. As he fled the squad car he was suspected of vandalizing, McDonald reportedly entered a Burger King parking lot. But when Walsh and Van Dyke sped into the parking lot behind him, McDonald ran back onto Pulaski Avenue. The response car gave chase, while McElligott's limping car trailed behind. Before long the rapid response car was closing in on McDonald from behind. It then occurred to Van Dyke that if he opened the car door from the passenger side, he could use it as a battering ram, and knock McDonald to the ground. Van Dyke abandoned this plan, however, when he saw yet another squad car approaching from the opposite direction.

The response car then circled around until it was close to McDonald, and Van Dyke exited the vehicle. At this point, he and McDonald were 20 feet away from each other. Another squad car was approaching from behind McDonald, and an empty field was to his right. With nowhere else to run, McDonald, according to Van Dyke, started to advance towards him, while extending his knife out. When he got out of the car, Van Dyke said he could see McDonald's face, and promised he won't soon forget the expression it held-or rather, the lack thereof:

"His face had no expression," Van Dyke said from the stand. "His eyes were just bugging out of his head. He had just these huge white eyes, just staring right through me."

Van Dyke said that he began yelling at McDonald to drop the knife. But McDonald kept advancing towards him. He got "about 10-15 feet away," Van Dyke said, "We never lost eye contact," he proclaimed. His "eyes were bugging out" and "his face was just expressionless," Van Dyke repeated, before describing how McDonald threatened him with the knife. "He waved the knife from his lower side upwards, across his body towards my left shoulder," Van Dyke said, claiming that it was only after McDonald made this movement that he began to shoot.

Van Dyke claimed that he had no idea if he had accidentally hit him when he started to fire. Eventually, though, McDonald fell to the ground. Once Van Dyke realized he had fallen, he recalls that he stopped shooting. But then he saw McDonald moving. "I could see him starting to push up, with his left hand, off the ground. I see his left shoulder start to come up. I still see him holding that knife with his right hand, not letting go of it. And his eyes were still bugged out. His face has got no expression on it."

While McDonald was on the ground Van Dyke said that he was still yelling at him to "drop that knife." He couldn't say how many times he yelled at McDonald. All he knew was that McDonald would not obey. Now fixated on the knife itself, Van Dyke pointed his gun and shot at it. "I just wanted him to get rid of that knife," he said.
There is much evidence suggesting that the testimony given by Van Dyke was fantasy, or distorted from reality, given the video footage. Here "fantasy," refers to the textbook definition, which can be found, for example, in the 2019 Merriam-Webster Dictionary in which the word is defined as "a fanciful mental image, typically one on which a person dwells at length or repeatedly, and which reflects their conscious or unconscious wishes." Another, related meaning of fantasy is "an idea with no basis in reality."18

Scholars in the field of African American studies also have a long tradition of thinking about this term. For Ellen Samuels (2014, p. 3), fantasies are key to the way American institutions, such as the police, create a social hierarchy based on the color of a person's skin. In the US race operates as an obvious, biological mark of identity, to the point that US residents often believe they can see a person and quickly place them in the racial category in which they are said to belong. But race is not merely about the way skin color operates as an "embodiment of physical difference," as Samuels puts it, nor is it a phenotypic feature that people can simply choose to ignore, as Bonilla-Silva (2013) writes, the concept is also about the way commonsensical, seemingly "reasonable" ideas about a person's identity merge with fantasies, which have real consequences for people's lives.

The Story of the Knife-Wielding Black Man with the Bugged Out Eyes, may sound familiar to those versed in the history of US stereotypes. In the US, the mythology of the Black criminal has often been premised on the idea that Black people pose a threat to "polite" society. As Van Dyke spoke, one can almost see D.W. Griffith's 1915 film, Birth of a Nation, playing in black-and-white in the courtroom above his head like a cartoon bubble that betrays his inner thoughts. The film was once praised by President Woodrow Wilson for its artistry and political commentary; and, in it, Griffith advanced portrayal after portrayal of Black male criminals as the primary threat to society in the aftermath of the Civil War (Rhodes, 1993; Williams, 2002; Singh 2004). Based on a popular 1905 novel, The Clansman, Griffin's cinematic makeover is now thought to be responsible for the rebirth of the Klu Klux Klan, and the thousands of lynchings its members and other vigilantes enacted between Reconstruction and World War II (Mitchell, 2011).

Considering that Laquan McDonald was a Black teenager from Chicago, who was killed for a crime he was never convicted of, this incident resonates with the historic case of another Chicago teenager, Emmett Till. Till was lynched while visiting his family in Mississippi after a White woman claimed that he whistled at her. The vigilantes who hunted, tortured, and killed Till were all exonerated. Like Till, McDonald was killed before he was ever found guilty of a crime; and even if he had been found guilty, that particular crime would not have warranted the death penalty-all of which suggests that McDonald was not killed because of the actual threat he posed. It is more accurately said that McDonald fell victim of the perception or fantasy of Black predatory violence. This fantasy of Black predatory violence is so ingrained in US culture that a police officer could determine that, to avoid a murder conviction, his most viable legal strategy is to try to convince the twelve jurors tasked with deciding his fate that the seventeen-year-old who he shot sixteen times possessed the exceptional strength required to bring a knife to a gunfight-and come out the victor.

A part from the cultural mythology that transforms Black masculinity into caricature or hyperbole-a form of fantasywhat makes Van Dyke's version of events fanciful is the profound way that it contradicts what can be observed from the dash cam video footage. Watching the video, it would be easy to conclude that Van Dyke is blatantly lying about the circumstances of the shooting. But the question that matters to the court is not 
whether what he is saying contradicts the video evidence before the jury. It clearly does. The question is whether or not Van Dyke believes his own version of events. His testimony thus focuses on his own "mental image" of the shooting, and the jury is asked to separate the question of whether he was actually in danger from whether the police officer thought he was in danger.

A clue that this shooting represented a deeply felt desire to shoot someone who Van Dyke sees as threatening comes from the initial pursuit. All Van Dyke knows from McElligott's radio transmission is that someone has punctured the tires of a squad car. The way he characterizes that person is telling. That person could be merely a nuisance or a vandal. Yet Van Dyke describes him as a threat, which makes McDonald, in Van Dyke's eyes, eligible to be shot. (Recall that he asks his partner Walsh: if someone was "attacking" McElligott and his partner, then why didn't they shoot him?) Also relevant, of course, is the fact that Van Dyke seemed resigned to the idea that he would "have to" use his gun that night. (Recall that he said: "Oh my God, we're going to have to shoot the guy," two blocks before reaching McDonald). This is how and why Van Dyke's determination to shoot McDonald before any encounter with him ever takes place can be seen as a conscious or unconscious wish to kill him that eventually comes to fruition.

In addition to this desire to use gun violence as a way to minimize the threat he faces, what makes Van Dyke's version of events fanciful is the way that he repeatedly fixates on the idea that McDonald poses a threat to his life. Watching the proceedings, it becomes clear that evidence of this obsession is palpable in the court: there was Van Dyke's preoccupation with McDonald's knife such that after he shoots McDonald, enough times for his body to spin around and fall to the ground, Van Dyke still believes that McDonald could raise from the ground, evade more bullets from the other police officers on the scene, and get close enough to overpower him. There was the curious fact that Van Dyke claims to shoot at the knife while McDonald is bleeding to death. Van Dyke said he shot at the knife, even though as a police officer he was trained to shoot a person in the six inch-wide region below the throat and above the navel where, police calculate, they have the best chance of hitting someone, the region that police officers refer to as "center mass." And there was the fact that Van Dyke shoots until his gun is empty, until there are no more bullets left.

Listening to Van Dyke, on this day, one can see that the idea of Black threat that overcame him that night had little basis in reality. After all, it is Van Dyke's sworn testimony that he believed that the seventeen year-old who he shot sixteen times was still endangering his life even after he was lying on the pavement. But there are other ways that Van Dyke's testimony defies reality. Van Dyke said that McDonald was advancing towards him with a weapon. In reality, the opposite was true: Van Dyke opened fire while walking towards McDonald. Van Dyke's testimony also gives the impression of a standoff, with McDonald charging him. But in reality, McDonald was never facing Van Dyke (and so it would have been difficult to see his "bugged out" eyes): the police officer approaches and then shoots McDonald from the side.

To help foment the idea that police officers like Van Dyke are always in danger, inherently, by virtue of their occupation, Van Dyke's lawyers attempt to turn McDonald into the quintessential Black predator. In his closing remarks, for example, Van Dyke's defense attorney, Dan Herbert, said: "If Laquan McDonald did not appear to be some kid whacked out on PCP, acting really bizarrely, if this was a kid in a Boy Scout uniform just walking down the street with a knife and Jason Van Dyke shot him, yeah, it probably wouldn't be justified." The corollary to this statement, of course, is that because McDonald seemed to be high on drugs, the shooting was justified.
In painting McDonald as a drug addict to excuse his client's actions, Herbert, in defense of Van Dyke, is not merely alluding to the Black predators that Birth of a Nation made famous, he is also echoing a more recent notion of the "superpredator" that Hillary Clinton drew attention to in a 1996 speech. ${ }^{19}$ Speaking in support of the Violent Crime Control and Law Enforcement Act, signed into law two years prior to her speech, Clinton addressed the need to punish Black urban youth: “...they are not just gangs of kids anymore. They are often the kinds of kids that are called superpredators-no conscience, no empathy. We can talk about why they ended up that way, but first, we have to bring them to a heel." When this quote resurfaced during Hillary Clinton's 2016 presidential run, it drew substantial criticism from criminal justice reform advocates. Even so, instead of apologizing, Bill Clinton, while campaigning on behalf of his wife, doubled down on the superpredator trope: "I don't know how you would characterize the gang leaders who got 13-year-old kids hopped up on crack and sent them out onto the street to murder other African American children," the former President said. ${ }^{20}$ For the former president, "superpredator" was still the appropriate term.

Part of Herbert's defense strategy was to characterize McDonald as a "superpredator." By describing his expressionless face, indicative of someone with "no empathy" or "no conscience," as Hillary Clinton said, and repeatedly calling attention to his "bugged out" eyes, indicative of someone who is "whacked out on PCP," as Herbert said, Van Dyke was drawing attention to the widely held belief that a person like that needed to be brought "to heel" by law enforcement. What is happening in the courtroom when a police officer is trying to convince the jury that he truly believed that a boy being shot was not the victim, but an aggressor who could overcome the assaults against his body and kill with determination? Van Dyke needs at least some of the jurors to see the fantasy of Black predatory violence before them in the figure of Laquan McDonald. And in a sense it worked: Van Dyke was convicted of second-degree murder and 16 counts of aggravated battery. Crucially, he was not convicted of first-degree murder, which would have meant that he intended to "kill or do great bodily harm" to McDonald. This charge would have acknowledged that he knew that shooting him sixteen times would cause death, and that such an extreme use of force was "without lawful justification."

The gun and the contradictions of race. On January 18, 2019, Judge Vincent Gaughan of the Cook County Circuit Court, sentenced Jason Van Dyke to almost seven years in an Illinois prison. Nine months later, a Somali American police officer named Mohamed Noor shot and killed a white woman of Australian heritage by the name of Justine Ruszcyk. The shooting took place only a few miles away from Falcon Heights, where Philando Castile was killed, in the neighborhood of Fulton. The circumstances of the Ruszcyk shooting were as follows: on July 15,2017 , Ruszcyk called the police because she heard screams and feared that a woman was being sexually assaulted in the alley behind her house. Noor and his partner Matthew Harrity responded to the call, but they did not see any activity - that is, until Justine Ruszcyk approached them. Perhaps she intended to tell the police officers that it was she who made the call, or that the screams in the alleyway had come from teenage lovers, or that a woman had been assaulted like she assumed and had just stumbled away. Whatever Ruszcyk meant to say, one can never know because when she approached the vehicle, Harrity "got spooked," and fearing an "ambush," drew his weapon. Sensing his partner's fear, Noor was even more aggressive. He pulled out his gun and fired a bullet through the open squad car window, past Harrity's head and into Ruszcyk's chest, killing her. ${ }^{21}$ 
Like Van Dyke, Noor said he fired his gun because he believed that "there was a threat," and added that he felt his partner "feared for his life." ${ }^{22} \mathrm{He}$ was charged with the same crime (second-degree intentional murder) that Van Dyke was convicted of. But unlike Van Dyke's decision to shoot McDonald 16 times, the jury in Noor's case could not be certain that he intended to kill Ruszcyk. Instead of locking him up for the exact crimes the prosecution had sought, they convicted Noor of third-degree murder, which means that he was found guilty of causing her death by perpetrating an "eminently dangerous" act, but that he committed this act "without intent." The jury also found Noor guilty of second-degree manslaughter, meaning that he created an "unreasonable risk" and was negligent when he killed Ruszcyk. Noor was sentenced to 12 and half years in prison-five and a half more years than Van Dyke, for a more severe crime. The city also awarded Justine Ruszcyk's family \$20 million, which, according to The New York Times, is "among the largest ever for a police shooting in the United States." 23 Notably the Ruszcyk's received \$15 million more from Minneapolis' municipal government than the McDonald's did from the City of Chicago. $^{24}$

One can speculate, of course, but there is no way to know if the "glittery cellphone" in Ruszcyk's hand would've been mistaken for a knife, had she been Black like McDonald. There was, however, a racial fantasy at work in this case as it was in McDonald's, only it did not apply to the person who was shot. It applied to the shooter. Shortly after Ruszcyk's death, a former Congresswoman, Michele Bachmann, just a year removed from representing Minnesota's 6th congressional district at the time of the incident, said: "Noor comes from the mandated cover-up women culture. That's why I'm wondering if they'll ask whether his cultural views led him to shoot her," she finished, referencing his African and Islamic background. ${ }^{25}$ At the trial, Noor's supporters argued that his treatment in the press was indicative of a double standard: "This case is about a black Muslim immigrant," a member of the Somali-American community said. "They are worried about disappointing the white community," he added, referring to the City's legal team. Next to this man was another from the large refugee population, who held up a sign, which read: "Wrong Complexion For Blue Protection."26

In leading newspapers across the US, opinion writers proclaimed that Noor would not have faced the same level of scrutiny had he been white. ${ }^{27}$ Mohamed Noor was the first Minnesota police officer to be convicted of a fatal shooting in decades. In the US it is extremely rare for an officer to even be charged in such a case. Consider that the police officer who shot and killed Philando Castile walked free, even though Castile had been shot six more times than Ruszcyk. Also, unlike Castile's case, there was an immediate and undeniable fallout from Ruszcyk's shooting: In response to how the shooting was handled, the Minneapolis Mayor Besty Hodges fired the Chief of Police, Janeé Harteau, claiming that the city had lost faith in her. ${ }^{28}$ The publicity surrounding this shooting was a major part of the reason why Mayor Hodges herself lost her reelection bid in $2017^{29}$-all of which is to say that it took a white woman being shot and killed by the police for many residents of Minneapolis to see the issue of police force as the societal threat that it has always been for African Americans.

\section{Conclusion: learning from the legend}

When I was the same age as Laquan McDonald, I remember reading from a raggedy high school textbook, issued to me by the state of Georgia, that the gun, or rather the right to bear arms represented a safeguard against governmental infringement. I also recall my AP US history teacher telling me that, in addition to being able to possess guns, the Second Amendment guarantees the right to form 'a well-regulated militia.' I soon discovered that the 'well-regulated' part of that proclamation was up for interpretation, and that militias could be a ragtag group of armed men; and when I realized this, I remember wondering whether or not these militias, and the police, were ever at odds with each other. Little did I know then, in some southern cities, residents argued that the police should patrol the streets without guns. I think knowing that would've helped me a great deal in high school, when I first started getting harassed by the police. Back then it seemed like common sense that the police should be able to carry guns and kill people. I had already learned that, as an African American teenager, the police would be more likely to kill me than any of my white peers, if for some reason, they took me as a threat. But what I hadn't yet learned was the legend of BrasCoupé.

Learning the legend of Bras-Coupé is to acquire knowledge about the people who were once considered property during the classic period of European expansionism, when it became possible, as Mills (2014) once said, "to speak with no sense of absurdity of 'empty' land that are actually teeming with millions of people." Learning the Legend of Bras-Coupé is to discover that the logic of the slave patrol justifies the police officer's gun, which is to say the police's use of force, it is to remember that while the white public eventually acquiesced to the idea that the police should be armed, in some major cities, they only did so to suppress the Black population, who they regarded as a threat. Learning the legend is to be informed of how politicians during this period would summon the image of the slaves in the swamplands to remind the public about the potential for organized revolt. That is how the wilderness where maroon communities of fugitive slaves and Native Americans lived came to be considered the boundary of civilization, "the natural state" from with civil society emerged (Trouillot, 2003). Learning the legend of Bras-Coupé is to remember that the specific law that allows a police officer to shoot to kill when he or she feels afraid is rooted in a "color-blind" ideology that does not see race, despite the US's history of enslavement, and even though a disproportionate number of African Americans are shot and killed by the police in the United States. ${ }^{30}$ Learning the legend of Bras-Coupé is to be at odds with a legal system that promotes a worldview that emphasizes individualistic explanations to justify police violence-explanations, which suggest, for example that if Laquan McDonald was dressed like a Boy Scout, he would not have found trouble that night. Learning the legend of Bras-Coupé is to understand that police violence is rooted in the African American experience, and it is to pay particular attention to the communal strategies Black people have developed for transmitting knowledge about the law, as Kenya was doing in our interview. What I am suggesting is that the old Black American folk poem, "Got one mind for white folks to see, another for what I know is me," helps us grasp and better interpret the ways that African Americans have always had to manage law enforcement's fantasies of them.

One way that Black people have dealt with fantasies of predatory violence is by flipping them into self-affirming folklore:

According to legend, the moment that Bras-Coupé loses his arm is precisely the moment he gains his superpowers. Yet, instead of viewing his impairment as a deficit, the legend speaks of premonitions and prophecies. Squire predicted that one day he would become Bras-Coupé before he was ever captured, and, in this way, "a self emerges where it is not supposed to exist” (Ford, 2015).

There has been so many occasions, especially over the course of my many years grappling with the problem of police violence, when I have contemplated why we (Black people) need legends 
and heroes like Bras-Coupé. I have come to realize that, asserting the self, that is, one's humanity in the face of police violence, has been an important way that Black folks carry the long history of Black bodily injury with us. This is why anthropologist, Melville Herskovits (1941), called the legend of Bras-Coupe "one of the richest stores of data" on Black culture in the nineteenth century; it is why antebellum-era authors like Castellanos (1905) and novelists like George Washington Cable, 1879, 1910) and dramatists like Frederick Delius wrote about the legend (Randel, 1971); it's why artists like Lafcadio Hearn drew sketches of BrasCoupé as a heroic figure (Ladd, 1991); it's why musicians like Marcus Christian recorded songs about him (Hessler, 1987); it is why Bras-Coupé has been reincarnated in the 2012 film, "Django Unchained," for a new generation of movie-goers, and as Luke Cage in the 2016 Netflix show for Marvel comic book fanatics.

So when I say that Laquan McDonald became Bras-Coupé on October 20,2014, it is not to suggest that he did not suffer an inglorious death. It is to highlight the fact that unlike Justine Ruszcyk who was humanized by the police and the press as soon as she was killed, Laquan McDonald, from the moment of his encounter, was hyper-visible in one sense, profoundly unseen in another, and all the while, a symbol of the hardships that have accompanied daily survival for Black people in the US. It is to point out, in other words, that cultural coping mechanisms cannot solve the inherent problem with the police's use of force that allows officers to kill at their own discretion-which brings me back to the last few minutes of my interview with a twenty-five-year-old middle school teacher and organizer from Chicago.

"There's just so much to say about these shootings," she said, towards the end of our discussion, after we had been talking about the McDonald case for quite some time, "and it's impacting so many people." Kenya went on to say that the topic reaffirms her belief in abolition. "Whenever I talk about abolition people feel like it's unrealistic. And I understand that. Abolition probably won't happen in my lifetime. And it may not ever happen. But I think that when you think creatively about alternatives to policing, when you start really asking questions about people's first encounter with the police, and how the police typically treat them, and what kind of force they've been subjected to, you start to see the problem of police violence in a different light." She ended our conversation by focusing on the police officer's gun: "When you recognize the historical pattern of these incidents of police force, it becomes difficult to see police shootings as an accident or an anomaly." For Kenya, police homicides served a purpose, and when I asked her what that purpose might be, she said the shootings serve to: "perpetuate the lie that Black people are inferior and violent and need to be put down." It is this lie and its contradictions, which, for centuries, has justified the use of guns in the hands of the police, and the logic of the slave patrol.

\section{Data availability}

The datasets generated during and/or analyzed during the current study are not publicly available because data associated with this project are still being collected as part of a multi-year study. In the future the data may be available from the corresponding author on reasonable request.

Received: 18 June 2019; Accepted: 24 September 2019; Published online: 29 October 2019

\footnotetext{
Notes

1 For full report, see: https:/www.ussc.gov/sites/default/files/pdf/research-andpublications/research-publications/2017/20171114_Demographics.pdf
}

2 Ibid, 2.

3 Ibid, 2.

4 For the ProPublica report, see: https://www.propublica.org/article/deadly-force-inblack-and-white

5 Ibid.

6 Ibid.

7 See: https://mappingpoliceviolence.org/aboutthedata

8 See: https://mappingpoliceviolence.org/

9 See: Louisiana Advertiser 1834

10 Ibid.

11 In qualitative social science, saturation refers to the principle that further data collection is unnecessary because the ideas and themes have become so repetitive that they can be taken as an accurate reflection of a group's perspective as a whole. The question of when saturation is reached depends on the nature of the research being collected and the questions being asked (Guest et al., 2006).

12 "Kenya" is a pseudonym for one the participants in this study.

13 I did not find the exact title of the article that Kenya mentioned. But I did find the following article, which I presume is the article she was referring to: https://www. nytimes.com/interactive/2017/01/18/upshot/some-colleges-have-more-studentsfrom-the-top-1-percent-than-the-bottom-60.html?mtrref=www.google. com\&gwh=FF79E16A70ED04DC605108AC44822466\&gwt=pay

14 Following Kenya's lead, this paper will treat both lethal injection and the police's use of force as forms of state-sanctioned violence that are similar in that they disproportionately impact African Americans.

15 Prieur, Denis, "Message from the Mayor to the City Council," 21 January1836, City Archives, New Orleans Public Library.

16 There are many different renditions of the Legend of Bras-Coupe. In this article, I am referring to the relationship between the story itself, and its politicizationparticularly in relation to the early use of force debates in the United States. Bryan Wagner's (2010) work is the first to place these specific issues in conversation with one another.

17 Discussion of the specific elements in the shooting are gleaned from the courtroom testimony in Jason Van Dyke's murder trial. A transcript of Van Dyke's testimony can be accessed here: https://chicago.suntimes.com/2018/10/5/18452134/chicagopolice-officer-jason-van-dyke-s-testimony-in-court-word-for-word

18 Hanks P (2009) Stephen J. Perrault (ed) Merriam-Webster's Advanced Learner's English Dictionary.

19 Hillary Clinton's full speech can be accessed here: https://www.youtube.com/watch? $\mathrm{v}=\mathrm{j} 0 \mathrm{uCr}$-7ePno

20 For Bill Clinton's heated exchange with Black Lives Matter activists, see: https://www. npr.org/2016/04/07/473428472/bill-clinton-gets-into-heated-exchange-with-blacklives-matter-protester

21 For the details of Ruszcyk's shooting, see: https://www.nytimes.com/2019/04/13/us/ mohamed-noor-trial-minneapolis.html

22 Ibid.

23 For the details of the settlement for the Ruszcyk family, see: https://www.nytimes. com/2019/06/07/us/minneapolis-police-sentencing-mohamed-noor.html

24 For the details of the settlement for the McDonald family, see: https://www. chicagotribune.com/news/breaking/ct-met-laquan-mcdonald-jason-van-dyke-court20180816-story.html

25 For Bachmann's statement, see: https://slate.com/news-and-politics/2017/07/theresponse-to-justine-damonds-killing-by-mohamed-noor.html

26 For coverage of the Noor trial, see: https://www.nytimes.com/2019/06/07/us/ minneapolis-police-sentencing-mohamed-noor.html

27 On the controversy surrounding Noor's treatment, see: https:/www.aclu.org/blog/ criminal-law-reform/reforming-police-practices/what-officer-noors-conviction-saysabout-racism

28 See: Smith, Mitch (July 21, 2017). "Minneapolis Police Chief Forced Out After Fatal Shooting of Australian Woman." The New York Times.

29 See: Erin Golden, In Mayor Betsy Hodges' re-election loss, Minneapolis voters were 'looking for something different', Star Tribune (November 11, 2017).

30 For year-by-year data on the disproportionate killing of African Americans at the hands of the police in the US, see: mappingpoliceviolence.org

\section{References}

Bonilla-Silva E (2013) "New racism," color-blind racism, and the future of Whiteness in America." In: White Out. Routledge, pp 268-281

Cable GW (1879) Old Creole Days. New York: Charles Scribner's Sons.

George Washington Cable (1910) The Creoles of Louisiana. Harvard Social Studies Textbooks Preservation Microfilm Project; 02826. Scribner's Sons, New York

Castellanos HC (1905) New Orleans As It Was: Episodes of Louisiana Life. Second Edition. New Orleans: The L, Graham Co., Ltd., Publishers

Dixon TL(2008) Crime news and racialized beliefs: understanding the relationship between local news viewing and perceptions of African Americans and crime" J Commun 58(1):106-125 
Ford III JE (2015) Blackness and Legend. Black Camera:Int Film J 7(1):199-217

Hastings WG (1900) The development of law as illustrated by the decisions relating to the police power of the state. Proc Am Philos Soc 39(163):359-554

Herskovits MJ (1941) The Myth of the Negro past. 1st edn. In: Harvard Anthropology Preservation Microfilm Project; 00221. Harper \& Bros, New York; London

Hessler MS (1987) Marcus Christian: the man and his collection. Louisiana Hist 28 (1):37-55

Ingersoll TN (1995) Slave codes and judicial practice in New Orleans, 1718-1807. Law and History Review 13(1):23-62

Genovese ED (1992) From rebellion to revolution: Afro-American slave revolts in the making of the modern world. LSU Press, Baton Rouge

Ladd B (1991) An atmosphere of hints and allusions: Bras-Coupé and the Context of Black Insurrection in "The Grandissimes". South Quart 29(3):63

Guest Greg, Bunce Arwen, Johnson Laura (2006) How many interviews are enough? An experiment with data saturation and variability. Field methods 18(1):59-82

Mills CW (2014) The racial contract. Cornell University Press, Ithaca

Mitchell K (2011) Living with lynching: African American lynching plays, performance, and citizenship. 1890-1930. University of Illinois Press, Champaign

Randel W (1971) Frederick Delius in America. The Virginia Magazine of History and Biography 79(3):349-366

Rhodes J (1993) Race and cultural production: responses to the birth of a nation: the visibility of race and media history. Critical studies in mass communication 10(2):184-190

Samuels E (2014) Fantasies of identification: disability, gender, race. NYU Press, New York

Singh NP (2004) Black is a Country. Harvard University Press, Cambridge

Trouillot MR (2003) Anthropology and the savage slot: The poetics and politics of otherness. In Global Transformations. Palgrave Macmillan, New York, pp 7-28

Wagner B (2010) Disturbing the peace: black culture and the police power after slavery. Harvard University Press, Cambridge

Williams ER (1972) Slave Patrol Ordinances of St. Tammany Parish, Louisiana, 1835-1838. Louisiana Hist: J Louisiana Hist Assoc 13(4):399-412
Williams L (2002) Playing the race card: melodramas of black and white from Uncle Tom to OJ Simpson. Princeton University Press, Princeton Wish H (1939) The slave insurrection panic of 1856. J South Hist 5(2):206-222

\section{Competing interests}

The author declares no competing interests.

\section{Additional information}

Correspondence and requests for materials should be addressed to L.R.

\section{Reprints and permission information is available at http://www.nature.com/reprints}

Publisher's note Springer Nature remains neutral with regard to jurisdictional claims in published maps and institutional affiliations.

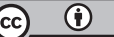

Open Access This article is licensed under a Creative Commons Attribution 4.0 International License, which permits use, sharing, adaptation, distribution and reproduction in any medium or format, as long as you give appropriate credit to the original author(s) and the source, provide a link to the Creative Commons license, and indicate if changes were made. The images or other third party material in this article are included in the article's Creative Commons license, unless indicated otherwise in a credit line to the material. If material is not included in the article's Creative Commons license and your intended use is not permitted by statutory regulation or exceeds the permitted use, you will need to obtain permission directly from the copyright holder. To view a copy of this license, visit http://creativecommons.org/ licenses/by/4.0/.

(C) The Author(s) 2019 